\title{
Russia's new East Asian policy: a rational strategy or a self-delusion?
}

\author{
Pavel Minakir \\ Academician, \\ Economic research institute FEB RAS \\ Khabarovsk, Russia
}

\author{
Olga Prokapalo \\ Doctor of economic sciences, \\ Economic research institute FEB RAS \\ Khabarovsk, Russia
}

\author{
Alexander Goryunov \\ Candidate of economic sciences, \\ Economic research institute FEB RAS \\ Khabarovsk, Russia
}

\begin{abstract}
Russia's "new Eastern policy" was inaugurated in 2012, when the APEC Summit was held in Vladivostok. Since then the policy had retained its original intention of reorienting Russia's economy towards East Asia, drawing it away in relative terms from Russia's traditional economic partners in Europe. To some extent Russia was even successful in achieving the policy's goal. However, the crisis caused by economic sanctions and the fall of oil prices in $\mathbf{2 0 1 4}$ had caused a reformulation of both the role of East Asia in Russia's foreign economic relations and the practical approaches Russia employs to achieve the "new Eastern policy's" goal. This goal was effectively merged with that of developing the Russian Far East, which became seen as Russia's platform for integration with East Asia. The approaches to the development of the Far East have also been affected by the shortage of public funds for meaningful development programs which necessitated a shift to a "creative institutional approach" to regional development. This paper explores these themes and their implications for the Russian Far East and Russia's East Asian policy.
\end{abstract}

Keywords - Far East, Asian-Pacific region, institutions of development, foreign economic relations, economic integration

The most popular topic of discussion today having to do with Russia's Eastern regions is the so-called "new Eastern policy". This policy is not entirely new, of course - it has a history of some depth, which is explored in [10]. The first mention of this policy can be traced back to the crisis of 19981999. However, the first resulting significant public investment (primarily in export infrastructure) arrived in the Far East only in 2006 after Vladivostok was selected as a host city for the APEC Summit.

The primary component of the current iteration of the "Eastern policy" is "the turn to the East", which is usually understood as the goal of reducing Russia's traditional reliance on Europe as its primary foreign economic partner by way of increasing economic cooperation with East Asian economies. Judging solely by Russia's foreign trade performance of the last 8 years, the policy would appear to have been largely successful in achieving the stated goal (TABLE I. )

TABLE I. GEOGRAPHY OF RUSSIA'S FOREIGN TRADE, \% OF TOTAL TRADE

\begin{tabular}{|l|l|l|}
\hline \multicolumn{1}{|c|}{ Country groups } & $\mathbf{2 0 0 8}$ & $\mathbf{2 0 1 6}$ \\
\hline EU & 52,0 & 43,1 \\
\hline APEC & 20,4 & 30,0 \\
\hline CIS & 14,5 & 12,1 \\
\hline Other countries & 13,1 & 14,8 \\
\hline
\end{tabular}

However, these changes in the geographic constitution of Russia's trade were, at least in some part, due to a significant reduction of the country's total trade since 2014. This reduction was due to a dual effect of economic sanctions imposed on Russia in 2014 and the subsequent fall of oil prices. Of these two causes, the latter certainly had the more profound effect on Russia's trade with the rest of the world, but in any case - the sharp decline of foreign demand for Russia's main export item - crude oil, prompted the surfacing of doubts in Russia regarding the prospects of further trade and investment cooperation with European countries. These doubts were further exacerbated by the massive outflows of capital from the Russian economy which at the time were believed to have been precipitated mostly by economic sanctions. For the moment, the solution to both Russia's foreign trade and foreign investment woes was believed to lie in East Asia.

This sudden rise of East Asia's perceived importance for Russia's global economic prospects gave new impetus to the "Eastern policy". If before 2014 East Asia was seen as important mostly as part of (rather vague) plans for the 
development of the Russian Far East, then after 2014, East Asia became seen as being important for the development of the entire national economy. To recall, the connection between East Asian cooperation and Far Eastern development took on an official flair just two years prior - in 2012, when President Putin proclaimed the development of the Russian Far East as a national priority of Russia going into the 21 st century.

The facts of the matter, however, soon became apparent: the majority of Russia's population and the bulk of its economy situated in the West, the Russian heartland is separated from East Asia by several thousand kilometers of space and a serious infrastructural gap. Therefore, the strategy of reliance on East Asia as a partner in foreign trade and investment for the nation at large had naturally morphed into the goal of developing the Far East as a "national platform" for Russia's economic cooperation with East Asia. In other words, if before 2014 East Asian cooperation was seen as a tool for the development of a major Russian region - the Far East, then after 2014 the development of the Far East became a tool for promoting East Asian cooperation.

In practice, achieving the goal of Far Eastern development in its reformulated form required finding solutions to the same two fundamental problems. The first of which is the Far East's lack of population and continuing outmigration. Indeed, in the 25 years since the collapse of the Soviet Union the Far East had lost almost 2 million people (TABLE II. ).

TABLE II. POPULATION OF RUSSIAN FEDERAL DISTRICTS (WITHOUT REPUBLIC OF CRIMEA AND THE CITY OF SEVASTOPOL), MLN PEOPLE.

\begin{tabular}{|l|l|l|l|}
\hline \multicolumn{1}{|c|}{ Territory } & $\mathbf{1 9 9 1}$ & $\mathbf{2 0 1 6}$ & $\begin{array}{c}\text { Growth (+) / } \\
\text { decline (-) }\end{array}$ \\
\hline Central federal district & 38,1 & 39,1 & $+1,0$ \\
\hline Northwestern federal district & 15,2 & 13,8 & $-1,4$ \\
\hline Volga federal district & 31,9 & 29,7 & $-2,2$ \\
\hline Southern federal district & 13,6 & 14,0 & $+0,4$ \\
\hline North-Caucasian federal district & 6,6 & 9,7 & $+3,1$ \\
\hline Ural federal district & 12,7 & 12,3 & $-0,4$ \\
\hline Siberian federal district & 21,1 & 19,3 & $-1,8$ \\
\hline Far Eastern federal district & 8,0 & 6,2 & $-1,8$ \\
\hline Russian Federal - total & 147,2 & 144,1 & $-3,1$ \\
\hline
\end{tabular}

At the same time, as TABLE II. shows, only three federal districts in Russia had gained population between 1991 and 2016. Siberia had lost nearly the same proportion of its 1991 population as the Far East, and the Volga district fared even worse.

However, population loss is not even the real problem for the Far East's economic interaction with East Asia. The true problem lies in the fact that no one can tell what size of population the Far East requires to serve as Russia's "interface" to East Asia. The entire population of Russia (including Crimea) is 146 million people. There are over 100 million people living just south of the Russian-Chinese border. Using that proportion as a metric, we can conclude that Russia's entire population would have to be relocated to the Far East to achieve a "demographic parity" with China. That conclusion is clearly absurd but it does not preclude the goal of increasing the Far East's population from being included in every relevant government program.
The second problem has to do with the concept of "weak economy" in the Far East. It is believed that the region's weak economy is the chief reason for the region's demographic troubles and its inability to serve as Russia's "window to Asia". However, in the recent 8 years (as illustrated in Fig. 1) the Far Eastern economy had lagged behind the Russian average only in investment. All other major macroeconomic indicators were well above or roughly at the national average levels. While the lagging investment can be explained with the drastic cuts in public investment in the region after the APEC Summit in Vladivostok (which required massive infrastructure investment in excess of 10 bln USD) was concluded in 2012.

Fig. 1. Change in main macroenomic indicators of Russia and the Far East in in $2016(2009=100 \%)$, \%

Even comparing household incomes (by the logic implicit in the "weak economy" thesis - the chief factor of outmigration from the Far East) in the Far East to the Russian average, we see a situation which is hardly worse than the national average, especially in the recent years (Fig. 2).

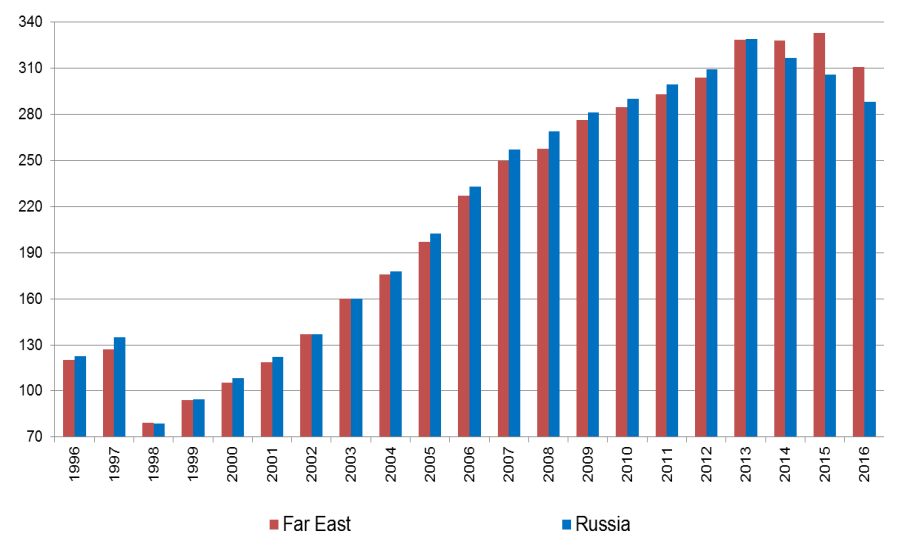

Fig. 2. Real household income index $(1995=100 \%), \%$

It is needed to note, of course, that the positive dynamic in Pictures 1 and 2 is due in large part to Yakutia and Sakhalin with their large export sectors. However, even when accounting for that factor the overall picture in the Far East is still optimistic.

The general structure and dynamics of foreign trade in the Far East are also close to the national average. The trends in the region's foreign trade in the recent years mostly coincided with those of Russia's total trade. The main difference had been the late start of the crisis in the Far East where the drop in external trade occurred in 2015 versus 2014 for the rest of Russia (Fig. 3). 


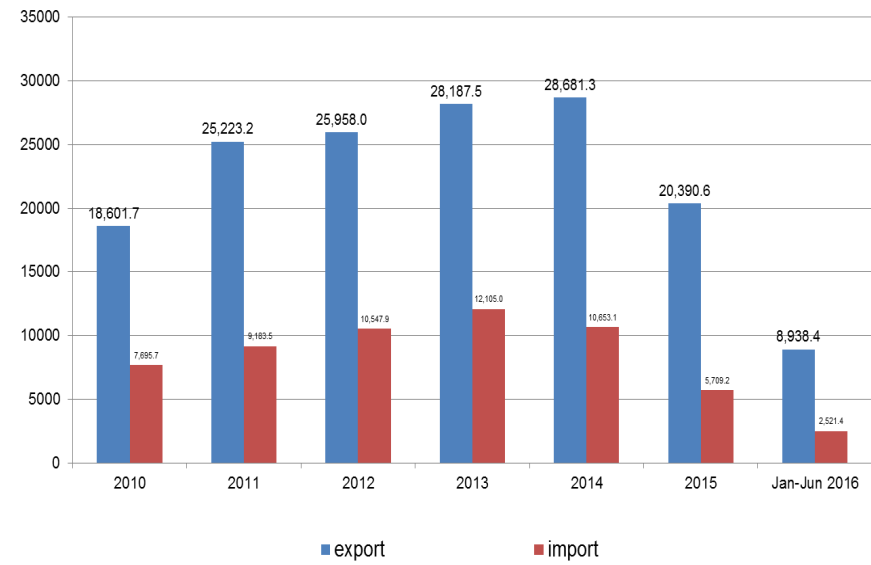

Fig. 3. Foreign trade of the Russian Far East, mln USD

As far as geography of the region's foreign trade is concerned, the only viable trade partners of the Russian Far East are situated in the Asian Pacific region ${ }^{1}$. Nearly $80 \%$ of the Far East's trade is with North-East Asian and ASEAN countries. That settles the matter of integration with East Asia, as far the Far East itself is concerned.

The region's trade with CIS countries, on the other hand, had all but seized since 2015. To a great degree, this was due to the high share of Ukraine in total trade of the Far East with CIS countries. The crisis in bilateral Russian-Ukrainian relations resulted in significantly increased political and financial risks for Russian companies in trading with Ukraine. For the Far Eastern businesses these increased risks, coupled with traditionally high costs of transportation, meant that trade had become largely unprofitable.

The Far East's main foreign trade market can be further narrowed down to North-East Asia (NEA), meaning almost exclusively the "Big Three" countries of that subregion: China, Japan, and Republic of Korea. The shares of these countries in the Far East's trade had been remarkably stable over the past few years (TABLE III. ).

TABLE III. THE FAR EAST'S TRADE WITH NEA COUNTRIES, \%

\begin{tabular}{|l|l|l|}
\hline & \multicolumn{1}{|c|}{$\mathbf{2 0 1 0}$} & \multicolumn{1}{|c|}{$\mathbf{2 0 1 5}$} \\
\hline China & 26,6 & 24,5 \\
\hline Republic of Korea & 23,8 & 24,4 \\
\hline Japan & 26,4 & 27,8 \\
\hline
\end{tabular}

Another area of economic cooperation is exchange of capital. In light of Russia's national priorities discussed above, this area of the Far East's cooperation with East Asia is in fact more important than foreign trade. Foreign investment in the Far East is highly uneven across its constituent regions. Practically all (over 90\%) foreign investment is concentrated in the Sakhalin oblast, more precisely - in the oil and gas projects situated on the Sakhalin shelf. Investigating the patterns of foreign investment in the rest of the Far East

1 And foreign economic cooperation with Asian Pacific nations has been the norm for the Far East historically, what changed was only the level and degree of cooperation. reveals the main obstacle for any plans to use the Far Eastern development as a platform for Russia's integration in East Asia. That obstacle is the lack of trust of foreign investment towards the proclaimed goals and projects of economic development of the Far East. This lack of trust had limited foreign investment in the Far East to date to several medium sized projects in the automotive and oil processing industries, and infrastructure. The bulk of foreign investment is still targeted at the offshore oil and gas projects on Sakhalin.

Moving on from foreign economic relations of the Far East, we proceed to the next important factor of economic wellbeing of regions in Russia as anywhere else: the state and regional budgets. Budget expenditures are especially important as a component of demand where the private sectors of the economy is relatively underdeveloped, which is still the case in Russia as a whole and most of its regions.

In this area, we note an interesting transformation which had occurred between 2008 and 2016. A surplus of 133.2 bln rubles of the consolidated budget of all Far Eastern subjects of Federation in 2008 had turned into a deficit of 244 bln rubes in 2015. The source of this deficit is presented in TABLE IV. . The total income collected in the Far Eastern district in 2008 exceeded 245 bln rubles, with 212 bln rubles (87\%) retained by the Far Eastern regions and an additional 292 bln rubles coming in form of transfers from the federal budget. The situation had changed drastically in 2015: over 700 bln rubles were collected in the Far Eastern district with 470 bln rubles $(67 \%)$ retain in the district and 300 bln rubles transferred from the federal budget. Put into relative terms, the total income of the consolidated Far Eastern budget as share of income collected in the Far Eastern district in 2008 amounted to almost $206 \%$, the same number for 2015 was only $110 \%$. In other words, while the Far Eastern budget's income today still exceeds the region's own fiscal resources, but only barely as compared to 2008 . The source of the past fiscal prosperity was of course the oil and gas export rent incomes, collected in full by the federal budget. The loss of this rent had resulted for the Far East (along with other Russian regions) in a serious budget crisis.

TABLE IV. INCOME OF THE CONSOLIDATED BUDGET OF THE FAR EASTERN FEDERAL DISTRICT, BLN RUBLES

\begin{tabular}{|l|l|l|}
\hline \multicolumn{1}{|c|}{$\mathbf{2 0 0 8}$} & \multicolumn{1}{|c|}{$\mathbf{2 0 1 5}$} \\
\hline $\begin{array}{l}\text { (1) Collected in the } \\
\text { federal district }\end{array}$ & 245.6 & 703.9 \\
\hline $\begin{array}{l}\text { (2) Retained in the federal } \\
\text { district }\end{array}$ & 212.2 & 473.7 \\
\hline $\begin{array}{l}\text { (3) Received as federal } \\
\text { transfers }\end{array}$ & 292.6 & 300.9 \\
\hline $\begin{array}{l}\text { Total income of the } \\
\text { district's consolidated } \\
\text { budget }(2+3)\end{array}$ & 504.8 & 774.6 \\
\hline
\end{tabular}

The conclusion from the above analysis is that the Far East by itself lacks the financial, capital, or human resources to be a "stand in" for Russia in its economic interactions with East Asia. This was obviously also the conclusion drawn by economic planners in regard to the Far East: the region isn't large enough economically and needs to be "developed". And 
since any accelerated economic development requires (at the minimum) financial resources and the oil rent had nearly evaporated the only viable solution was to find "creative" ways to develop the region with nearly no additional resources. Three such "creative" recipes have been proposed to date:

1. Territories of accelerated social-economic development (TORs) ${ }^{2}$.

2. The free port Vladivostok.

3. The "Far Eastern hectare".

These "recipes" were codified in respective federal laws and supported by four newly established organizations:

1. Foundation for the development of the Far East.

2. Human capital development agency in the Far East.

3. Far Eastern agency for the attraction of investment and export support.

4. Far East Development Corporation.

All of these institutions (including the federal and resulting regional legislation) share the same basic goal of promoting investment in the Far East.

The chief of the above listed institutional recipes is certainly the TORs. This institution is well known both abroad and in Russia itself under the general moniker of "special economic zones". The first thing potential investors were told about the TOR incarnation of special economic zones is that they will provide for better business conditions then those available in Singapore. However, of the long list of business considerations important for investors, which includes but is not limited to cost and quality of labor, market demand and access infrastructure, political risks, etc, only lower taxes were offered in TORs.

The second recipe is the free port of Vladivostok. The authors of this institutional innovation were likely inspired by the historic existence of a free port regime in Vladivostok (or rather - in all Far Eastern sea ports) in the Tsarist Russia. In practice, "free port Vladivostok" is to date more of a slogan or a general memorandum of intentions rather than a concrete mechanism for the attraction of investment and promotion of economic growth.

The third recipe - the Far Eastern hectare - is aimed primarily at changing the migration trend in the Far East and attracting population to the region. This institution offers a hectare of land in the Far East to every resident of Russia free of any charges. The "free as in beer" principle was broken, of course, when it collided with the multitude of lower level regulations that impose various fees and charges related to land use. The law stipulates that persons receiving the land must start using it in some fashion within the first 3 years of receiving it. As of March 1, 2017 a total of 67,000 applications have been filed by people wishing to receive their "hectares", and around 10\% of these applications had been approved. The "Far Eastern hectare" program had been

${ }^{2}$ A number of authors deal with these institutional innovations, either generally [[4], [7], [8], [9]] or with particular institutions: TORs [[6]], free port Vladivostok [0]. plagued with inevitable technical problems having to do with land registration and zoning which required serious efforts on the part of the relevant federal agencies to resolve.

More generally, the "Far Eastern hectare" program, just as the "free port" one, appears to be inspired by history. The free allotment of land in the Far East had already occurred almost 150 years ago, at the dawn of the region's colonization by Russia ${ }^{3}$. However, the region had changed fundamentally since that historically remote time. The structure and scale of the region's economy are completely different today from what they were a century and a half ago. Personal motivations of people living there or moving to or from the region are completely different. The country that the Far East is part of is also no longer a predominantly agricultural one. The Far East since the first years of its colonization had been turned into an industrial and heavily urbanized macroregion. That leaves little hope for the success of the "hectare" program, at least in what concerns the goal of attracting massive migration or investment to the region.

What the Russian government's economic planners think of the efficacy of this new institutional system for the development of the Far East can be gleaned from economic projections contained in the new generation of strategic planning documents, which are being prepared by governments of the Far Eastern subjects of Federation [11, 12, $13,14,15,16]$. These projections are best characterized as "cautiously optimistic" and suggest that the government is rather conflicted in its assessment of its own development program for the Far East.

On the one hand, the total cumulative growth of population in the Far Eastern federal district is expected to reach a mere $3.7 \%$ by 2025 , with an average annual growth rate of $0.4 \%{ }^{4}$. On the other hand, fairly optimistic average annual GRP growth rates are projected for the same period. They significantly differ across regions, varying from the high of $8.5 \%$ in Amurskaya oblast to the low of $2.2 \%$ in Kamchatskyi krai but yield the regional average of $4.7 \%^{5}$. This GRP growth, however, is based on high projections of private investment (for a total of 9.5 trln rubles in 2016-2025) and clash with projected population growth: GRP projections likely assume unrealistic values of investment multipliers. At the same time, public investment between 2016-2025 is projected to amount to a total of only 420 bln rubles across all Far Eastern subjects of Federation. That $4.2 \%$ of public investment as a share of total against the backdrop of relatively high GRP growth and near zero population growth reflects the general outlook of Russia's economic planners towards the Far East's development, both in and of itself and as a platform for Russia's integration in East Asia: hope for

${ }^{3}$ We'd like to suggest that practical application of historical precedents should ideally follow a study of those precedents. Studies of the history of settlement of the Far East is presented in [[2], [3], [4], [5]].

${ }^{4}$ These numbers are based on the "Complex plans of social-economic development" of the Far Eastern subjects of Federation.

${ }^{5}$ Ibid. 
the current institutional paradigm to work but don't bet too much on it.

All of the above leads us to the following conclusions. Firstly, there are no "silver bullets" in regional development both the historical evidence and the current state of affairs in the Far East's economy suggest that the overall efficiency of the current development paradigm of "creative institutionalism without money" is likely to be low. Secondly, the Russian government economic planners are mostly aware of that, even if they avoid admitting it directly. Thirdly, the Far East is not very special - the region has no problems that other Russian regions wouldn't have. The problems are the same as everywhere else: lack of investment, outdated economic structure, technological gaps with foreign competitors in many industrial markets, underdeveloped financial sector, etc. In other words, the Far East by itself and for itself is doing fine. At least it is doing as fine as other Russian macroregions are doing. It is developing at a natural pace and any attempts to speed up that pace will require more than just institutional "creativity" - they'll require public finances. However, that is the one thing that is currently in short supply.

\section{References}

[1] Avdeev Yu.A. The Free Port of Vladivostok - Pros and Cons. EKO [ECO]. 2017. No. 2. Pp. 5-26. (In Russian)

[2] The Anthology of Economic Thought in the Far East. Issue 1. Colonization Processes in Priamurye Region at the Turn of $20^{\text {th }}$ Century. Khabarovsk, 2008. 208 p. (In Russian)

[3] The Anthology of Economic Thought in the Far East. Issue 2. Researching the Rural Economy of the Priamurye Region between the Russian-Japanese and the $1^{\text {st }}$ World War. Khabarovsk, 2009. 288 p. (In Russian)

[4] Demyanenko A.N. On the Strategic Initiatives for Development of Russian Far East in the Context of Historical Experience. Regionalistica [Regionalistics]. 2016. Vol. 3. No. 3. Pp. 6-13. (In Russian)
[5] Demyanenko A.N., Dyatlova L.A. Far East: Modern Strategically Innovations and Lessons of History. EKO [ECO]. 2017. No. 4. Pp. 4560. (In Russian)

[6] Isaev A.G. The Territories of Accelerated Development: New Instrument of Regional Economic Policy. EKO [ECO]. 2017. No. 4. Pp. 61-77. (In Russian)

[7] Minakir P.A. New Eastern Policy and Economic Realities. Prostranstvennaya economika = Spatial Economics. 2015. No. 2. Pp. 711. DOI: 10.14530/se.2015.2.007-011 (In Russian)

[8] Minakir P.A. From the Chief Editor. Prostranstvennaya ekonomika $=$ Spatial Economics. 2014. No. 1. Pp. 7-11. DOI: 10.14530/se.2014.1.007-011. (In Russian)

[9] Minakir P.A., Prokapalo O.M. Russian Far East: Economic Phobias and Geopolitical Ambitions. EKO [ECO]. 2017. No. 4. Pp. 5-26. (In Russian)

[10] Turn to the East: The Development of Siberia and Far East in the Face of Increasing Asian Vector of Russian Foreign Policy. Moscow, 2016. 448 p. (In Russian)

[11] Long term prognosis of social-economic development of Primorskyi krai until 2030. // 2016. [URL: http://primorsky.ru/authorities/executiveagencies/departments/economics/smb/\%D0\%94\%D0\%BE\%D0\%BB\%D 0\%B3\%D0\%BE\%D1\%81\%D1\%80\%D0\%BE\%D1\%87\%D0\%BD\%D1 \%8B\%D0\%B9\% 20\%D0\%BF\%D1\%80\%D0\%BE\%D0\%B3\%D0\%BD\% D0\%BE\%D0\%B7\%20418-\%D1\%80\%D0\%B0.rar]

[12] Proposal of the Strategy of social-economic development of Khabarovskyi krai until 2030 // 2016. [URL: https://www.khabkrai.ru/?menu=getfile\&id=30800]

[13] Addendum to the long term prognosis of social-economic development of Khabarovskyi krai until 2030 // 2016. [URL: https://khabkrai.ru/?menu=getfile $\&$ id $=41602]$

[14] Proposal of the Strategy of social-economic development of the Jewish autonomous oblast until 2030 // 2017. [URL: http://economy.gov.ru/minec/resources/87705ea3-62f2-40fa-83b76b6eaae86390/EAO.pdf]

[15] Strategy of social-economic development of Kamchatskyi krai until 2030 // 2017.2030 [URL: http://strategy2030.kamgov.ru/uploads/page/files/KK do 2030 godared akcia 31052017 god.rar]

[16] Strategy of social-economic development of the Republic Sakha (Yakutia) until 2030 with a future target vision until 2050 // 2016. [URL: http://economy.gov.ru/wps/wcm/connect/c8ce61bd-8fca-401c-ba31244687acbefe/yakutstrate.pdf?MOD=AJPERES\&CACHEID=c8ce61 bd -8fca-401c-ba31-244687acbefe] 